\title{
Development and Usefulness of Hypernasality Control Device: A Preliminary Study
}

\author{
Yun-Kyung Song \\ Department of Speech Language Pathology \& Audiology, College of Health, Welfare and Education, Tongmyong University, Busan, Korea
}

\author{
Received: August 29, 2020 \\ Revised: September 21, 2020 \\ Accepted: October 4, 2020 \\ Correspondence: \\ Yun-Kyung Song, PhD \\ Department of Speech Language \\ Pathology \& Audiology, \\ College of Health, \\ Welfare and Education, \\ Tongmyong University, \\ 428 Sinseon-ro, Nam-gu, \\ Busan 48520, Korea \\ Tel: $+82-51-629-2128$ \\ Fax: +82-51-629-2019 \\ E-mail: voicesyk@hanmail.net
}

\begin{abstract}
The purpose of this study was to compare nasalance scores of the experimental paragraphs and sentences with and without 'Hypernasality Control Device (HCD)' and to determine the degree of foreign body sensation and pain with HCD. A 44-year-old normal adult woman wore type I and type II HCD, and then she was asked to read aloud the experimental paragraphs and sentences. Using a Nasometer, the nasalance scores were measured. The subject responded to a questionnaire with 5 -point scale to measure the degree of foreign body sensation and pain after wearing two types of HCD. In all experimental paragraphs and sentences, the nasalance scores with HCD were measured lower than those of without HCD. In addition, there was no foreign body sensation and pain with HCD, or it was at a slight level. These results showed that HCD played a role in regulating nasal resonance in a normal adult woman. It is expected that the HCD will contribute to the control of the nasalance scores in hypernasality subjects. And simplify the production process and continuous modification are required for efficient application and the appropriate HCD size and shape.
\end{abstract}

Key Words: Foreign body sensation, Hypernasality Control Device, Nasalance score, Pain.

\section{INTRODUCTION}

과다비성(hypernasality)은 비음을 제외한 자음 및 모음을 정상적인 방법으로 산출하는 동안 비강공명이 지나치게 많이 발생하는 것을 의미한다. 보통 이와 같은 증상은 연인두 부전 (velopharyngeal dysfunction)에 그 원인을 두고 있는데, 이는 비강으로 음파가 전달되지 않아야 할 때, 즉 비음이 아닌 소리 를 낼 때 비강 안으로 음파가 부적절하게 전달되는 것을 말한 다. 또한 비강누출(nasal emission)은 파열음, 파찰음, 마찰음과 같은 압력 자음을 산출할 때 연인두 부전으로 그 폐쇄가 적절 하게 이루어지지 않아 코로 기류가 새어나가는 현상이다. 이 새 어나가는 기류가 소리로 들리면 청취 가능한 비강누출(audible nasal emission)이라고 하며, 소리로 들리지 않으면 무음성 비 강누출(inaudible nasal emission)이라고 한다. 연인두 부전이 있는 대상자는 과다비성에 비강누출이 동반될 수도 있고 과다 비성만 있는 경우도 있다(Kummer, 2016).

일반적으로 중추신경계나 말초신경계의 질환이 연인두 부전 을 초래할 수 있으며, 특히 이완형과 경직형 마비말장애를 보이

(c) This is an Open Access article distributed under the terms of the Creative Commons Attribution Non-Commercial License (https://creativecommons.org/licenses/by-nc/4.0) which permits unrestricted non-commercial use, distribution, and reproduction in any medium, provided the original work is properly cited.
는 대상에서 과다비성 및 비강누출의 문제는 빈번하게 말 명료 도에 부정적 영향을 미치고 있는 것으로 보고되고 있다(Freed 2014; Duffy, 2016). 또한 선천성 기형인 구개열(cleft palate)이 있는 경우, 1 차 구개열 봉합 수술 후에도 흔히 연인두 부전을 나타낼 수 있다(Kummer, 2016).

한편 모든 말장애의 궁극적 치료 목표는 명료하고 자연스러 운 말이다. 의사소통장애 대상자의 최종 치료 목표가 말 명료 도의 향상이라고 할 수 있을 만큼 말 명료도는 아주 중요한 영 역이다. 말 명료도에 영향을 미치는 요인으로는 자음을 정확하 게 말하는 정도를 나타내는 자음정확도, 조음기관의 운동능력 을 나타내는 조음교대운동능력, 공명, 운율, 호흡, 발성 등이 있 다(Kim, 2002; Han, 2009). 이 요소들 중에서 공명문제는 행 동적 접근법인 언어치료 행위만으로 해결하기에는 한계가 있 다. 즉 연습을 통하여 기형이 있거나 약화 또는 마비된 근육이 정상적인 기능을 할 수 있게 하는 것은 어려움이 있고, 완전함 을 기대하는 것도 곤란하다.

이와 같은 이유로 구개열 아동은 1차 봉합수술 이후 연인두 부전이 있는 것으로 판단될 경우 보통 인두피판술(pharyngeal flap)과 같은 2차 수술을 하여 비강으로 소리가 새어나가는 것 을 조절하고자 한다(Yoo et al., 2000). 그러나 이 2차 수술은 만 4세는 되어야 가능해지기 때문에 초기 말소리 발달 문제가 
발생 가능한 공백이 생기게 된다(Kummer, 2016). 그 외에 구개 거상 보철기, 구개 폐쇄 보철기, 발화용 구 폐색 보철기 등으로 불리는 치과 보철기를 개별적으로 맞추어 착용함으로써 과다 비성이나 비강누출의 문제를 해결하려고 하지만, 착용의 불편 함(착용 부위의 통증 또는 구역반사를 초래)이나 비용 등의 문 제로 대중적이지는 않다(Heo et al., 2013). 행동적인 접근법의 하나로 언어치료 과정에 continuous positive airway pressure 을 활용한 연인두 근육의 강화 연습을 수행한 사례를 보고한 국내 연구가 있으나 충분한 효과를 보기에는 한계가 있었다 (Ha et al., 2012).

마비말장애의 경우, 해외 연구에 의하면 근위축축삭경화증 (루게릭병) 환자 25명을 대상으로 연인두 거상 보철기(soft platal lift prosthesis)를 착용하게 한 뒤 인터뷰를 통하여 84\%의 화자들이 보철기를 통한 증상 개선을 보고한 결과를 제시한 경우가 있으나(Esposito et al., 2000), 국내의 경우는 사례를 찾아보기 어렵다. 일반적으로 마비말장애로 인한 과다비성이나 비강누출이 있는 대상의 경우는 수술이나 보철장치를 적용하 기보다, 그 한계점에도 불구하고 언어치료를 통하여 말속도 조 절, 말소리 강도 조절, 구강 공명을 증대시키는 발성 방법을 연 습하는 등 행동적 접근법을 적용하는 경우가 대부분이다 (Duffy, 1995). Wenke et al.(2010)의 연구가 그 한 예인데, 이들 은 파킨슨병 환자에 적합한 음성치료 기법으로 Lee-Silverman Voice Treatment를 적용하여 음성 강도를 증가시켜 전반 적인 말 명료도를 향상시키고자 하였으나, 6 개월 후의 지속 상 태가 좋지 못한 한계점을 인정해야 했다. 뿐만 아니라 마비말장 애 대상자는 많은 수가 고령이며, 비가역적인 신경계 문제를 동 반한 경우이기 때문에 말 명료도를 높여 의사소통의 문제를 해 결하고 전반적인 삶의 질을 향상시키는 데에 관심을 갖기 어려 운 것이 현실이다.

우리나라 인구 약 5,170만 명 중 약 5\%인 261만 명이 등록된 장애인의 수이고, 이 중에서 의사소통장애를 보일 수 있는 청 각장애, 언어장애, 지적장애, 뇌병변장애, 자폐성장애에 해당하 는 장애인의 수만 합해도 89만 명에 이른다(Ministry of Health and Welfare, 2019). 또한 의사소통장애로 언어치료를 받는 대상의 약 $44 \%$ 가 말소리장애를 보이고 있다는 점(Kim et al., 2015)을 고려하면, 과다비성 및 비강누출 문제의 해결을 위 하여 기존의 보철기와 달리 접근성을 높인 조절기를 개발하는 것이 매우 의미 있는 과제라 할 수 있을 것이다.

이에 연구자는 과다비성이나 비강누출의 문제로 말 명료도 의 저하를 보이는 다양한 대상자에게 개별적이며 간단한 조절 기를 개발, 적용시킴으로써 말 명료도 향상과 의사소통 능력의 증진을 꾀하고자 하였다. 이를 위하여 2019년 메이커 문화 확 산 사업의 창작활동을 통하여 '과다비성 조절기(hypernasality control device, $\mathrm{HCD}$ )'를 제작하였다(과제번호: 메이커 창작활 동 10212817, 기간: 2019.06.01. 12.31.)

연구자가 메이커 창작활동을 통하여 제작한 '과다비성 조절 기'는 입천장에 밀착 고정시키는 치과 보철기와 달리 전비공을 통해 전비강에 삽입함으로써 통증이나 구역반사를 유발하지 않고, 쉽게 탈착이 가능하여 접근성을 높인 장치이다. 또한 역 류 방지 판막이 내장된 튜브 형태의 조절기(1형: 부착 판막 형 태 조절기, 2형: 이동 판막 형태 조절기)로 전비강 착용 시 들숨 이 자연스럽게 이루어지며, 말소리 산출이 이루어지는 날숨 시 자동으로 판막이 닫혀 과다비성이나 비강누출을 조절할 수 있 게 하였다.

따라서 개발되어 제작된 '과다비성 조절기'를 과다비성 및 비 강누출 대상자에게 적용함으로써 즉각적으로 말 명료도를 높 여 의사소통 과정에 항시 사용할 수 있는지, 혹은 언어치료 과 정에 적용할 수 있는지 그 효과를 확인하고 임상에 적용하는 것이 필요하다. 그러나 제작된 조절기가 과다비성 대상자에게 적용되기 전에 비강 착용 시 이물감이나 통증은 없는지, 구체 적인 말소리 산출 시에 어느 정도의 비음치 조절이 되는지, 그 정도를 파악하는 것이 우선적으로 요구된다.

이를 위하여 연구자는 개발된 두 가지 과다비성 조절기(1형, 2 형)를 정상 성인 피험자 1 인에게 직접 착용하게 하고 실험 문 단 및 문장을 말하게 함으로써, 1) 조절기 미착용 시 발화 문단 및 문장에 따른 비음치(nasalance sore)와 '과다비성 조절기'(1형, 2형) 착용 시의 비음치를 비교하고 2) '과다비성 조절기' 착용 시 이물감 및 통증의 정도를 파악하여 추후 과다비성 증상을 보이는 실제 대상자에게 적용해보기 위한 기초 자료로 사용하 고자 하였다.

\section{CASE REPORT}

\section{연구 대상}

본 연구는 과다비성 증상이 있는 대상자에게 '과다비성 조절 기'를 착용시켜 착용 효과를 살펴보는 실험을 하기 전에, 새로 개발된 조절기의 이물감 및 통증의 정도, 그리고 실제 발화 시 의 비음치 변화를 체크해보기 위하여 실시하는 예비 연구이므 로 증상을 가진 취약한 대상자를 섭외하거나, 다수의 학생을 대상자로 삼지 않고, 자발적 의지를 가진 정상 성인 1 인이 조절 기를 착용하게 하여 기초 자료를 수집하고자 하였다. 이를 위하 여 공명 및 음성, 조음과 말 명료도에 이상이 없으며, 구강 구조 및 기능에 결함이 없고, 신경계 질환이 없는 정상 성인을 대상 으로 평가하기로 하였다.

섭외된 연구 대상자는 위의 정상 조건에 적합하였으며, 개별 인식정보를 제공하지 아니하며, 피험자에게 요구되는 활동이 
과다비성 조절기를 전비강에 착용하여 이물감 및 통증의 정도 를 구술하고 체크리스트에 체크하는 것, 그리고 조절기 1형과 2 형의 착용 전과 후에 실험 문장 및 문단 읽기라는 것에 대하여 설명을 들었으며 이에 자유의지로 동의한 44세 정상 성인 여성 1 인이었다.

\section{연구 도구}

비음치(Nasalance score) 검사용 말 자료

비음치 평가는 선행 연구(Lee et al., 2005; Park et al., 2014) 의 검사용 말 자료를 참고하여 문장 또는 문단 수준에서 측정 하기로 하였다. 초성이나 종성이 1) 구강음으로만 이루어진 문 단, 2) 구강음과 비강음으로 이루어진 문단, 3) 비강음으로만 이 루어진 문장을 낭독하고, 각 조건(미착용 낭독, 조절기 1형, 2형 착용 시 낭독)마다 음향학적 분석장치로 비음치(nasalance score)를 측정하기로 하였다(Appendix 1). 이와 같이 다양한 압력 자음을 포함한 구강음 문단, 비강음이 일부이거나 전체가 비강음인 문단이나 문장을 낭독할 때의 비음치를 조절기 착용 전후로 비교하고, 나아가 한국인 정상 성인 비음치와 비교함으 로써 조절기의 비성 차단 정도를 파악할 수 있을 것이다.

\section{과다비성 조절기}

'과다비성 조절기'는 일반 성인을 대상으로 하여 인체 사용 가능한 경화제로 전비강의 본을 뜨고, 좌우 전비강의 본을 $3 \mathrm{D}$
스캐닝으로 데이터화하였으며, 디자인 목업(design mock-up) 과 워킹 목업(working mock-up) 과정을 거쳐 스캐닝 결과의 요철을 다듬고 단순화함으로써 간단한 튜브의 형태로 제작되 었다. '과다비성 조절기'의 시제품 형태는 Figure 1과 같다. 1형 인 부착 판막 형태 조절기는 튜브 상단에 붙어있는 얇고 납작 한 판막이 들숨에 위로 들어 올려지고, 날숨에 내려가면서 튜 브를 막아 비강 기류를 조절하게 되며, 2형인 이동 판막 형태 조절기는 들숨에 튜브 안에 있는 작은 볼이 위로 들어 올려지 고, 날숨에 내려가면서 튜브 통로를 막아 비강 기류를 조절하 게 된다. 두 가지 형태의 조절기 모두 전비강 속으로 깊이 들어 가는 문제가 발생하지 않도록 좌우 튜브를 하나의 고리로 연결 하였으며, 재질은 인체에 무해한 실리콘 러버를 사용하였다. 실 제 전비공을 통하여 전비강에 '과다비성 조절기'를 착용한 모습 은 Figure 2와 같다.

\section{음향 분석 기기: Nasometer}

비음치 분석을 위하여 음향학적 분석 도구인 NasometerII 6450 (PENTAX Medical, 3 Paragon Drive, Montvale, NJ, $\mathrm{USA})$ 을 사용하기로 하였다. 비음치(\%)는 [비강 산출 음향 에너 지/(비강 산출 음향 에너지 + 구강 산출 음향 에너지) $] \times 100$ 의 식으로 구해지며, 식에서 알 수 있듯이 발화 시 산출되는 전체 음향 에너지에서 차지하는 비강 산출 음향 에너지의 비율을 의 미한다. Nasometer는 침습적이지 않으며 코와 입 사이를 나누 는 격막을 사이에 두고 비강 앞과 구강 앞에 마이크가 달린 헤

Figure 1. Prototype of 'Hypernasality Control Device.' A: Attachment valve device. External assembly form (upper) and configuration (low). B: Movable valve device. External assembly form (upper) and configuration (low).
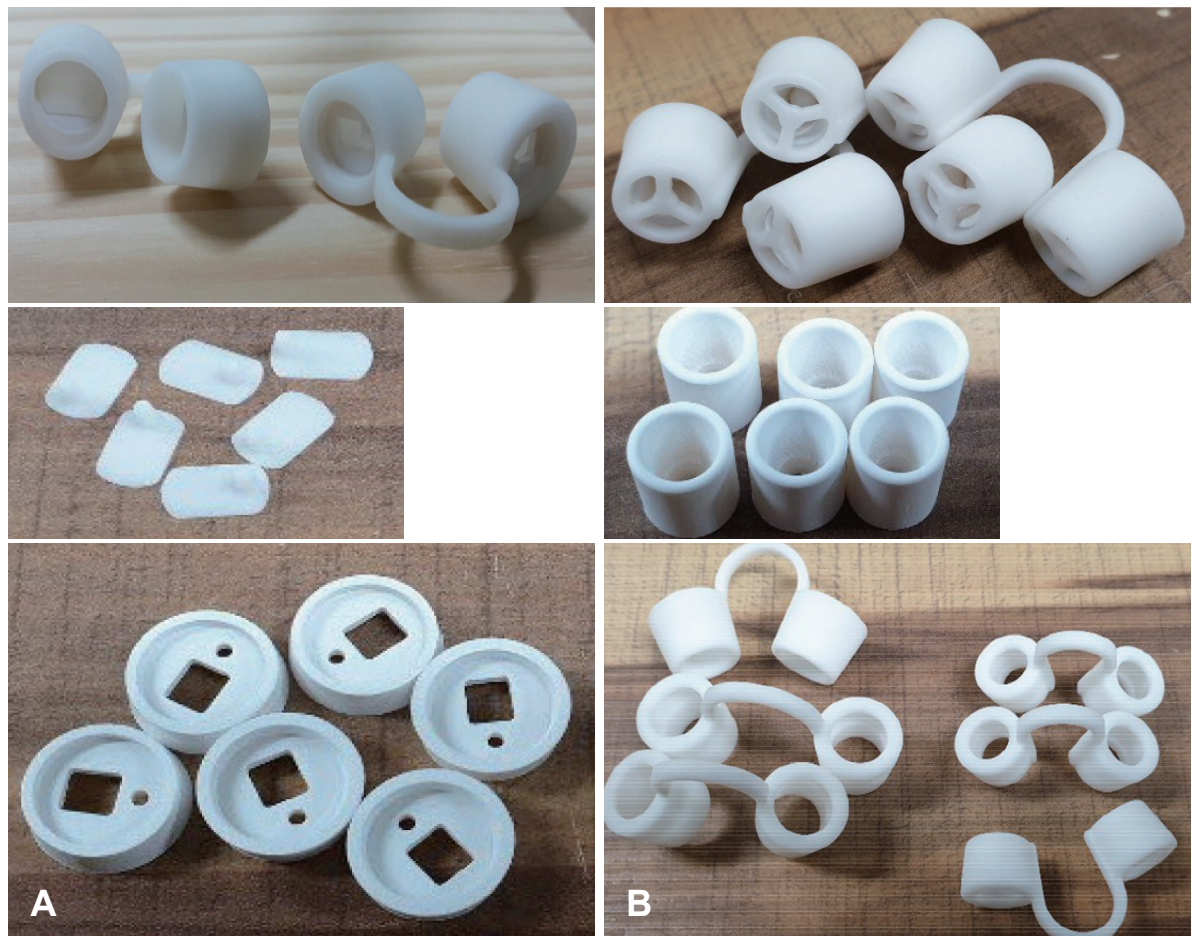

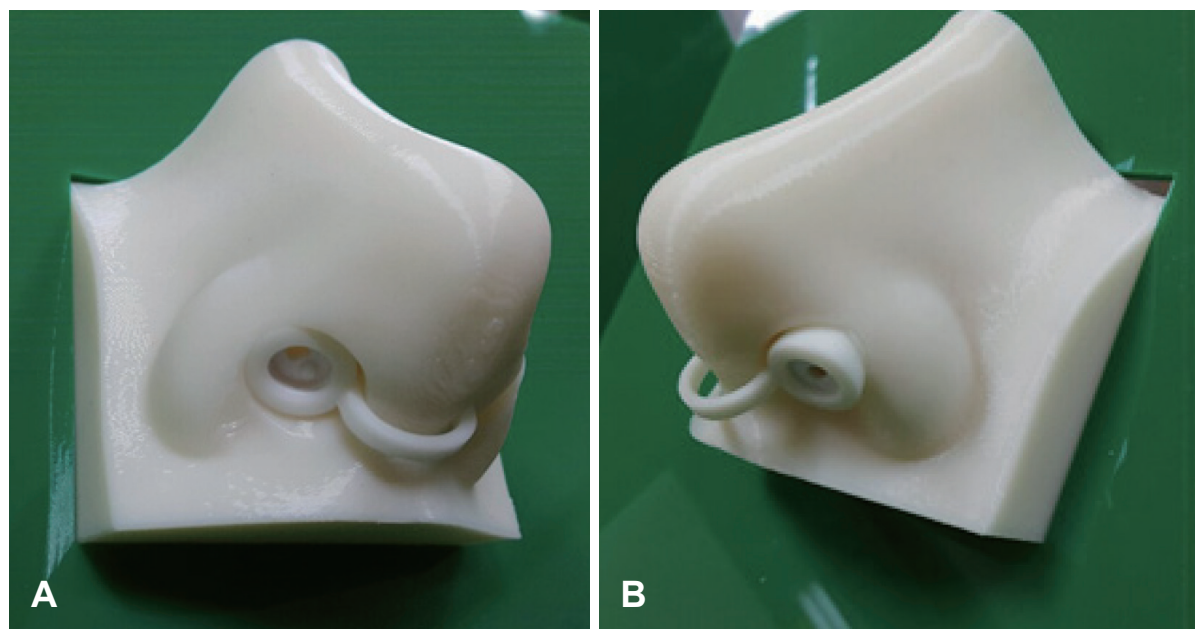

Figure 2. Wearing picture of 'HypernaSality Control Device.' A: Attachment valve device. B: Movable valve device.

드셋을 착용하고 발화함으로써, 검사한 발화의 비음치를 구할 수 있게 한다.

\section{주관적 평가 도구: 이물감 및 통증의 측정}

과다비성 조절기를 전비강에 착용하였을 때 감지될 수 있는 이물감 및 통증의 정도를 측정하기 위하여 간단한 5점 척도 설 문지를 만들었다(Appendix 2). 여기서 1점은 "이물감이나 통증 이 전혀 느껴지지 않는다.”를 의미하며, 5점은 “이물감이나 통 증이 매우 많이 느껴진다.”를 의미한다. 피험자는 1형과 2형 과 다비성 조절기를 착용하고 가만히 있는 상태, 그리고 주어진 평 가 문단 및 문장을 낭독할 때의 상태 각각에서의 이물감 및 통 증의 정도를 묻는 문항에 각각 체크하였다.

\section{연구 절차 및 분석}

\section{조절기 착용 후 안정 상태 및 읽기 상태에서 설문지 작성}

피험자는 조절기 착용 전에 실험 문단 및 문장을 읽는 연습 을 2회 실시하였다. 그 후 설문지에 대한 설명을 듣고, 연구자의 도움을 받아 조절기 1형과 2형을 각각 전비강에 삽입한 뒤, 착 용한 상태로 느껴지는 바를 묻는 설문지의 해당 문항에 체크하 였다. 또한 조절기를 착용한 상태로 실험 문단 및 문장을 읽고 난 뒤에, 그 상태에서 느껴졌던 바를 묻는 설문지의 해당 문항 에 체크하였다. 대상자는 각 경우의 주관적인 느낌을 자유롭게 말하였으며, 연구자는 수집된 설문지의 결과와 주관적 평가 내 용을 결과에 기술하였다.

착용 여부에 따른 실험 문단 및 문장 읽으며 Nasometer 평가 피험자는 조절기가 없는 상태에서 연구자의 도움을 받아 Nasometer를 착용하고 실험 문단 및 문장을 2회씩 읽었으며, 연구자는 데이터를 저장하였다. 또한 1형과 2형 조절기를 각각
착용한 상태에서 Nasometer를 착용한 뒤 각 문단 및 문장을 2 회씩 읽었으며, 연구자는 데이터를 저장하였다. 수집된 각 실험 문단 및 문장의 2 회의 비음치는 평균을 구하여 결과에 제시하 였다. 낭독 시 말속도 및 음성의 높이나 크기는 평소 말할 때와 유사하게 하였다.

\section{연구 결과}

조절기 미착용 상태의 피험자 비음치와 한국인 정상 성인 비음치와의 비교

피험자가 조절기 미착용 상태로 실험 문단과 문장을 2회씩 읽었을 때의 비음치와 한국인 정상 성인을 대상으로 동일한 실 험 문단과 문장으로 표준화한 비음치를 비교한 결과, 피험자의 비음치는 한국인 정상 성인 비음치(Park et al., 2014) 범위에 속 하는 것을 알 수 있었다(Table 1).

\section{1형 조절기 착용 및 미착용 시 비음치 비교}

피험자가 1형 조절기를 착용하고 실험 문단과 문장을 2회씩 읽었을 때의 비음치와 미착용 시의 비음치, 그리고 동일한 문단 및 문장에서의 한국인 정상 성인 비음치를 비교한 결과, 조절기 착용 시 비음치가 현저히 낮은 것을 알 수 있었다(Table 2). 또 한 한국인 정상 성인 비음치의 규준을 사용하여 역치(평균 \pm $1.96 \times$ 표준편차)를 구하고 조절기 착용 시 비음치와 비교한 결과, 구강음 문단의 경우만 역치 범위 안에 들어가며 나머지 구강음과 비강음 문단 및 비강음 문장의 경우는 모두 역치를 벗어난 과소 비음치라는 것을 알 수 있었다(Table 2).

\section{2형 조절기 착용 및 미착용 시 비음치 비교}

피험자가 2형 조절기를 착용하고 실험 문단과 문장을 2회씩 읽었을 때의 비음치와 미착용 시의 비음치, 그리고 동일한 문단 
Table 1. Comparison of nasalance scores in subject and Korean adults norm without Hypernasality Control Device

\begin{tabular}{|c|c|c|c|c|c|}
\hline \multirow{2}{*}{ Nasalance scores (\%) } & \multicolumn{3}{|c|}{ Subject } & \multicolumn{2}{|c|}{ Korean adults norm } \\
\hline & First & Second & Mean & Mean & $\mathrm{SD}$ \\
\hline Oral paragraph & 12.00 & 12.00 & 12.00 & 11.94 & 4.21 \\
\hline Oral and nasal paragraph & 35.00 & 33.00 & 34.00 & 34.73 & 4.79 \\
\hline Nasal sentence & 63.00 & 60.00 & 61.50 & 62.02 & 5.67 \\
\hline
\end{tabular}

Table 2. Comparison of nasalance scores in subject and Korean adults norm with and without HCD type I

\begin{tabular}{|c|c|c|c|c|c|c|c|c|c|}
\hline \multirow{2}{*}{ Nasalance scores (\%) } & \multicolumn{3}{|c|}{ With HCD } & \multicolumn{3}{|c|}{ Without HCD } & \multicolumn{3}{|c|}{ Korean adults norm } \\
\hline & First & Second & Mean & First & Second & Mean & Mean & $\mathrm{SD}$ & Threshold \\
\hline Oral paragraph & 5.00 & 4.00 & 4.50 & 12.00 & 12.00 & 12.00 & 11.94 & 4.21 & $3.69-20.19$ \\
\hline Oral and nasal paragraph & 10.00 & 10.00 & 10.00 & 35.00 & 33.00 & 34.00 & 34.73 & 4.79 & $25.34-44.12$ \\
\hline Nasal sentence & 25.00 & 36.00 & 30.50 & 63.00 & 60.00 & 61.50 & 62.02 & 5.67 & $52.61-73.13$ \\
\hline
\end{tabular}

HCD: Hypernasality Control Device

Table 3. Comparison of nasalance scores in subject and Korean adults norm with and without HCD type II

\begin{tabular}{|c|c|c|c|c|c|c|c|c|c|}
\hline \multirow{2}{*}{ Nasalance scores (\%) } & \multicolumn{3}{|c|}{ With HCD } & \multicolumn{3}{|c|}{ Without HCD } & \multicolumn{3}{|c|}{ Korean adults norm } \\
\hline & First & Second & Mean & First & Second & Mean & Mean & $\mathrm{SD}$ & Threshold \\
\hline Oral paragraph & 5.00 & 5.00 & 5.00 & 12.00 & 12.00 & 12.00 & 11.94 & 4.21 & $3.69-20.19$ \\
\hline Oral and nasal paragraph & 16.00 & 16.00 & 16.00 & 35.00 & 33.00 & 34.00 & 34.73 & 4.79 & $25.34-44.12$ \\
\hline Nasal sentence & 31.00 & 29.00 & 30.00 & 63.00 & 60.00 & 61.50 & 62.02 & 5.67 & $52.61-73.13$ \\
\hline
\end{tabular}

HCD: Hypernasality Control Device

Table 4. Comparison of nasalance scores with HCD type I and II

\begin{tabular}{|c|c|c|c|c|c|c|}
\hline \multirow{2}{*}{ Nasalance scores (\%) } & \multicolumn{3}{|c|}{ HCD type I } & \multicolumn{3}{|c|}{ HCD type II } \\
\hline & First & Second & Mean & First & Second & Mean \\
\hline Oral paragraph & 5.00 & 4.00 & 4.50 & 5.00 & 5.00 & 5.00 \\
\hline Oral and nasal paragraph & 10.00 & 10.00 & 10.00 & 16.00 & 16.00 & 16.00 \\
\hline Nasal sentence & 25.00 & 36.00 & 30.50 & 31.00 & 29.00 & 30.00 \\
\hline
\end{tabular}

HCD: Hypernasality Control Device

및 문장에서의 한국인 정상 성인 비음치를 비교한 결과, 조절 기 착용 시 비음치가 현저히 낮은 것을 알 수 있었다(Table 3). 또한 한국인 정상 성인 비음치의 규준을 활용한 역치와 조절기 착용 시 비음치를 비교한 결과, 구강음 문단의 경우만 역치 범 위 안에 들어가고 나머지 구강음과 비강음 문단 및 비강음 문 장의 경우는 모두 역치를 벗어난 과소 비음치라는 것을 알 수 있었다(Table 3).

\section{조절기 유형에 따른 비음치 비교}

피험자가 착용했던 조절기 타입에 따른 비음치를 비교한 결 과, 큰 차이가 없이 비슷한 비음치를 나타내는 것을 알 수 있었 다(Table 4). 또한 비음치가 특별히 더 많이 감소하는 조절기 유 형이 관찰되지는 않았으나, 1 형 조절기의 경우 구강음과 비강 음 문단을 말했을 때, 2형 조절기에 비하여 보다 더 낮은 비음 치를 나타내는 것을 알 수 있었다.
조절기 착용 후 이물감 및 통증에 대한 점수 및 주관적 느낌의 특성

피험자가 1형과 2형 조절기를 착용한 후 안정 상태 및 낭독 상태에서 각각 느낀 이물감과 통증에 대한 설문지(Appendix 2)를 작성하게 하고 그 점수를 살펴본 결과, 두 조절기 모두 두 가지 상태에서 이물감과 통증이 거의 느껴지지 않거나 아주 약하게 느껴지는 수준이라는 것을 알 수 있었다(Table 5). 또한 조절기 종류에 따른 이물감과 통증에는 큰 차이가 나타나지 않았다.

피험자가 자유롭게 표현한 주관적인 느낌들은 1) 2형 조절기가 들숨이 더 원활하다, 2) 조절기의 이물감이나 통증은 코에 얼마 나 정확하게 맞느냐에 따라서 달라질 수 있을 것 같다, 3) 조절기 높이가 더 낮아지면 더 편안한 착용감이 들 것 같다 등이었다.

\section{DISCUSSIONS}

본 연구는 '과다비성 조절기'를 과다비성 대상자에게 적용하 
Table 5. Scores of foreign body sensation and pain with HCD type I and II

\begin{tabular}{lcccccc}
\hline \multirow{2}{*}{ Scores } & \multicolumn{2}{c}{ HCD type I } & & \multicolumn{2}{c}{ HCD type II } \\
\cline { 2 - 3 } \cline { 5 - 6 } & & Just wearing state & Reading with HCD & & Just wearing state & Reading with HCD \\
\hline Foreign body sensation & 1 & 2 & 1 & 1 & 1 \\
Pain & 2 & 1 & 1 & 1 \\
\hline
\end{tabular}

HCD: Hypernasality Control Device

기 전, 정상 성인을 대상으로 전비강에 착용시켰을 때의 이물 감이나 통증의 정도 파악 및 미착용 시에 비하여 비음치가 어 떻게 달라지는지 확인하는 것을 목적으로 수행되었다. 그 결과 조절기 미착용 상태에서 피험자의 비음치는 한국인 정상 성인 의 비음치와 유사하였으나, 1형과 2형 조절기를 착용한 상태에 서는 미착용 시에 비하여 현저히 비음치가 감소하는 것을 확인 할 수 있었다. 또한 1 형과 2형 조절기 착용 시의 비음치는 구강 음으로만 이루어진 문단의 경우, 한국인 정상 성인 비음치 규 준에 따른 역치 범위 안에 들어갔으나, 구강음과 비강음이 공 존하는 문단과 비강음으로만 이루어진 문장의 경우는 역치 범 위를 벗어나는 낮은 비음치를 나타내었다.

이와 같은 결과는 과다비성 증상을 조절하기 위하여 개발된 ‘과다비성 조절기'가 명확한 비강 공명 차단 효과가 있다는 점을 보여준다. 즉 본 조절기의 개발 목적을 달성하였음을 부분적으 로 확인한 것이며, 두 가지 유형의 조절기 모두 유사한 효과를 보 인다는 점을 알 수 있었다. 이는 다양한 과다비성 대상자들이 본 조절기를 착용할 경우, 과다비성이나 비강누출이 조절되어 말 명료도의 향상을 즉각 체험할 수 있을 것을 기대하게 한다.

다만 비강음 및 구강음으로 이루어진 문단이나 비강음으로 만 이루어진 문장에서 이처럼 한국인 정상 비음치의 역치를 벗 어나는 낮은 비음치를 보였다는 점은 비음 말소리의 비강 공명 을 차단하는 효과가 과다한 경향이 있다는 점을 고려하게 한 다. 즉 1형, 2형 조절기 착용 시 구강음만으로 이루어진 문단에 서는 그렇지 않았으나, 비강음이 들어있는 문단이나 문장에서 한국인 정상 성인 규준에 의한 역치를 벗어나는 낮은 비음치를 보이는 점은 이 '과다비성 조절기'가 비강 공명이 이루어져야 할 상황에서도 정확하게 비강 공명을 차단하기 때문이라고 해석 해볼 수 있을 것이다. 또한 정상 공명 상태를 보이는 피험자의 경우이기 때문이기도 할 것으로 여겨진다. 이와 같은 결과는 추 후 정상 성인이 아닌 과다비성 대상자에게 직접 조절기를 착용 하게 하여 그 효과를 살펴보는 과정이 필요하다는 점을 제시하 고 있으며, 다른 한편으로는 조절기의 기본 구조는 그대로 두 되, 다양한 변형 모델을 개발하여 실험함으로써 적절한 수준의 비강 공명 차단 효과를 찾아내는 것이 필요하다는 것을 알려주 고 있다.

다른 한편, 조절기 미착용 시에 비하여 착용 시에 느껴지는 이물감이나 통증은 거의 느껴지지 않거나 그 정도가 미약한 것
으로 나타났다. 이는 본 '과다비성 조절기'가 다른 보철기들에 비하여 착용이 쉽고 불편함을 초래하지 않는다는 점을 확인할 수 있는 결과라고 해석된다. 다만 조절기 착용 후 피험자가 자 유롭게 제시한 의견들을 고려하면, 1형보다 2형에서 들숨 호흡 이 더 쉽게 가능하다는 점, 조절기의 사이즈와 형태에 다양한 변화를 주어보는 것이 필요하다는 점, 그리고 본 조절기가 좀 더 개개인의 전비강 모양 및 크기에 적합하게 제작되는 것이 바 람직하다는 점을 알 수 있었다. 그리고 이를 위하여 개개인의 전비강 본을 뜨는 과정과 $3 \mathrm{D}$ 스캐닝, $3 \mathrm{D}$ 프린팅 과정이 보다 단순해져야 하며, 신체 착용에 적절한 $3 \mathrm{D}$ 프린팅 소재의 개발 필요성이 제기되었다. 특히 Ayliffe et al.(2014)은 구개거상 보철 기의 모듈화를 시도하여 제작 과정의 복잡함, 수혜자의 불편함 을 감소시키고자 하였다. 재질 또한 아크릴 레진에서 실리콘으 로 바꾸어 부드러운 질감을 추구하여 치과에서 사용하는 보철 기의 새로운 대안을 마련하려는 시도를 보여주었다. '과다비성 조절기' 역시 개개인 맞춤형 혹은 기성 사이즈의 다양화 등 여 러 가지 방안들을 고려하여 보다 단순하게 제작되면서도 과다 비성을 조절하는 역할을 해내는 조절기를 완성하기 위한 노력 이 필요할 것으로 여겨진다.

본 연구는 ‘과다비성 조절기'의 개발 의의 및 과정을 요약하 였고, 그 유용성을 제시하기 위하여 정상 성인을 대상으로 조 절기 착용 전후의 비음치를 비교하였으며, 그 결과 비음치 조절 이 가능함을 확인할 수 있었다. 그러나 다양한 수준의 과다비 성을 보이는 환자를 대상으로 연구하지 못한 한계점이 있으므 로 앞으로 다양한 공명장애 대상자를 피험자로 하는 지속적인 후속 연구가 필요할 것으로 사료된다.

중심 단어 : 이물감·과다비성 조절기·비음치·통증.

\section{Ethical Statement}

This study was approved by the Institutional Review Board of Tongmyong University (IRB \# TUIRB-2020-013).

\section{Acknowledgments}

The author thank to the participant.

\section{Declaration of Conflicting Interests}

There are no conflict of interests.

\section{Funding}

N/A 


\section{ORCID iD}

Yun-Kyung Song

https://orcid.org/0000-0001-7466-0237

\section{REFERENCES}

Ayliffe, B. W., Bressmann, T., Al Mardini, M., \& Jokstad, A. (2014). Evaluation of a modular palatal lift prosthesis with a silicone velar lamina for hypernasal patients. The Journal of Prosthetic Dentistry, 112(3), 663671.

Duffy, J. R. (1995). Motor Speech Disorders: Substrates, Differential Diagnosis, and Management. St. Louis, MO: Mosby.

Duffy, J. R. (2016). Motor Speech Disorders: Substrates, Differential Diagnosis, and Management (Kim, H. H., Seo, M. K., Kim, Y. J., \& Yun, J. H., Trans.). (3rd ed.). Seoul: Pakhaksa.

Esposito, S. J., Mitsumoto, H., \& Shanks, M. (2000). Use of palatal lift and palatal augmentation prostheses to improve dysarthria in patients with amyotrophic lateral sclerosis: A case series. The Journal of Prosthetic Dentistry, 83(1), 90-98.

Freed, D. B. (2014). Motor Speech Disorders: Diagnosis and Treatment (Kwon, M. S., Kim, J. W., Lee, H. J., Choi, H. J., \& Ha, J. W., Trans.). (2nd ed.). Seoul: Pakhaksa.

Ha, S. H., Jung, S. E., \& Koh, K. S. (2012). Efficacy of CPAP (continuous positive airway pressure) therapy on reducing the degree of hypernasality in speakers with repaired cleft palate. Phonetics and Speech Sciences, 4(3), 171-177.

Han, J. S. (2009). Percentage of correct consonants, speech intelligibility, and speech acceptability in children with cleft palate. Communication Sciences and Disorders, 14(2), 183-199.

Heo, Y. R., Kim, J. W., Lee, G. J., \& Chung, C. H. (2013). Palatal obturator restoration of a cleft palate patient with velopharyngeal insufficiency: A clinical report. The Journal of Korean Academy of Prosthodontics, 51(4), 353-360.

Kim, S. J. (2002). The role of speech factors in speech intelligibility: A review. MALSORI, 43, 25-44.

Kim, S. J., Kim, M. J., Ha, S., \& Ha, J. W. (2015). A survey of speech sound disorders in clinical settings. Communication Sciences and Disorders, 20(2), 133-144.

Kummer, A. W. (2016). Cleft Palate and Craniofacial Anomalies: Effects on Speech and Resonance (Pyo, H. Y. \& Han, J. S., Trans.). (3rd ed.). Seoul: Pakhaksa.

Lee, E. K., Park, M. K., \& Son, Y. I. (2005). The compensatory articulation in the patients with cleft palate having velopharyngeal insufficiency. Journal of The Korean Society of Laryngology, Phoniatricsand Logopediics, 16(2), 118-122.

Ministry of Health and Welfare. (2019, December). [Status of the disabled $(2018,2019)]$. Statistics Korea. Retrieved from http://kostat.go.kr/portal/korea/kor_pi/8/7/index.board?bmode $=$ read\&aSeq $=372698 \&$ page $\mathrm{No}=16 \&$ rowNum $=10 \& a m S e q=\&$ sTarget $=\& \mathrm{sT} \mathrm{Tt}=$.

Park, M., Baek, W. S., Lee, E., Koh, K. S., Kim, B. K., \& Baek, R. (2014). Nasalance scores for normal Korean-speaking adults and children. Journal of Plastic, Reconstructive and Aesthetic Surgery, 67(2), 173-177.

Wenke, R. J., Theodoros, D., \& Cornwell, P. (2010). Effectiveness of Lee Silverman Voice Treatment (LSVT) on hypernasality in non-progressive dysarthria: The need for further research. International Journal of Language and Communication Disorders, 45(1), 31-46.

Yoo, Y. K., Han, J. S., Kim, J. L., \& Hwang, S. J. (2000) Speech-language evaluation before and after pharyngoplasty. Korean Journal of Cleft Lip and Palate, 3(2), 61-66. 


\section{APPENDICES}

\section{Appendix 1. 평가 문장 및 문단 리스트}

\begin{tabular}{lccc}
\hline \multicolumn{1}{c}{ 말소리 구성 } & 문장 및 문단 & $\begin{array}{c}\text { 비음치 } \\
\text { 평균(\%)음치 }\end{array}$ & 표준편차 \\
\hline 구강음 & “수희가족이 바다에 갔다. 배도 타고 튜브도 탔다. 갑자기 비가 와서 집으로 돌아왔다.” & 11.94 & 4.21 \\
구강음 및 비강음 & “오늘은 대공원에 놀러가는 날이다. 엄마가 김밥도 만드셨다. 과자랑 스케치북도 가져갔다.” & 34.73 & 4.79 \\
비강음 & “엄마 안녕 엄마 안녕, 나무 안녕 나무 안녕, 매미 안녕 매미 안녕.” & 62.02 & 5.67 \\
\hline
\end{tabular}




\section{Appendix 2. 과다비성 조절기 착용 시 이물감 및 통증의 정도 설문지}

\section{설 문 지}

귀하께서 과다비성 조절기 1형과 2형을 각각 전비강에 착용하고 가만히 있는 상태 혹은 착용하고 말하는 동안 느겨지는 점에 대 하여 문의드립니다. 아래의 문항을 읽고 적절한 점수에 체크하여 주십시오.

1. 과다비성 조절기 1 형의 경우

1-1. 조절기를 착용하고 가만히 있는 동안 전비강에 느껴지는 이물감의 정도에 대하여 체크하여 주십시오.

이물감이 전혀 느껴지지 않는다(1점) 이물감이 매우 많이 느껴진다(5점)

\begin{tabular}{|l|l|l|l|l|}
\hline 1점 & 2점 & 3점 & 4점 & 5점 \\
\hline & & & & \\
\hline
\end{tabular}

1-2. 조절기를 착용하고 가만히 있는 동안 전비강에 느껴지는 통증의 정도에 대하여 체크하여 주십시오.

통증이 전혀 느껴지지 않는다(1점) 통증이 매우 많이 느껴진다(5점)

\begin{tabular}{|l|l|l|l|l|}
\hline 1점 & 2점 & 3점 & 4점 & 5점 \\
\hline & & & & \\
\hline
\end{tabular}

1-3. 조절기를 착용하고 말하는 동안 전비강에 느껴지는 이물감의 정도에 대하여 체크하여 주십시오.

이물감이 전혀 느껴지지 않는다(1점) 이물감이 매우 많이 느껴진다(5점)

\begin{tabular}{|l|l|l|l|l|}
\hline 1점 & 2점 & 3점 & 4점 & 5점 \\
\hline & & & & \\
\hline
\end{tabular}

1-4. 조절기를 착용하고 말하는 동안 전비강에 느겨지는 통증의 정도에 대하여 체크하여 주십시오.

통증이 전혀 느껴지지 않는다(1점) 통증이 매우 많이 느껴진다(5점)

\begin{tabular}{|l|l|l|l|l|}
\hline 1점 & 2점 & 3점 & 4점 & 5점 \\
\hline & & & & \\
\hline
\end{tabular}




\section{2. 과다비성 조절기 2 형의 경우}

2-1. 조절기를 착용하고 가만히 있는 동안 전비강에 느껴지는 이물감의 정도에 대하여 체크하여 주십시오.

이물감이 전혀 느껴지지 않는다(1점) 이물감이 매우 많이 느껴진다(5점)

\begin{tabular}{|l|l|l|l|l|}
\hline 1점 & 2점 & 3점 & 4점 & 5점 \\
\hline & & & & \\
\hline
\end{tabular}

2-2. 조절기를 착용하고 가만히 있는 동안 전비강에 느껴지는 통증의 정도에 대하여 체크하여 주십시오.

통증이 전혀 느껴지지 않는다(1점) 통증이 매우 많이 느껴진다(5점)

\begin{tabular}{|l|l|l|l|l|}
\hline 1점 & 2점 & 3점 & 4점 & 5점 \\
\hline & & & & \\
\hline
\end{tabular}

2-3. 조절기를 착용하고 말하는 동안 전비강에 느껴지는 이물감의 정도에 대하여 체크하여 주십시오.

이물감이 전혀 느껴지지 않는다(1점) 이물감이 매우 많이 느껴진다(5점)

\begin{tabular}{|l|l|l|l|l|}
\hline 1점 & 2점 & 3점 & 4점 & 5점 \\
\hline & & & & \\
\hline
\end{tabular}

2-4. 조절기를 착용하고 말하는 동안 전비강에 느겨지는 통증의 정도에 대하여 체크하여 주십시오.

통증이 전혀 느껴지지 않는다(1점) 통증이 매우 많이 느껴진다(5점)

\begin{tabular}{|l|l|l|l|l|}
\hline 1점 & 2점 & 3점 & 4점 & 5점 \\
\hline & & & & \\
\hline
\end{tabular}

